\title{
最近の歯学
}

\section{5. 精密機械部門}

\section{緉維強化義歯床の成形}

東京医科歯科大学医用器材研究所精密機械部門 宮 入 裕 夫

アクリルレジンで成形される上顎全部床義歯の口蓋部 の板厚は通常 $1.6 \mathrm{~mm}$ と厚く, 咀嚼機能を低下させ, ま たレジンの熱伝導性の低いことから感覚的にもその特性 は十分なものではない。したがって,このような問題を 解决寸るため，熱云導性がすぐれ，かつすぐれた機械的 特珄を有するカーボン繊維 (CF) によるレジン床の強化 を行っている1)。しかし， 口蓋部の破壊を防止するた め, 口蓋部にCF クロスを強化材とする強化レジン床義 歯の成形は従来のレジン床に比べ難しく，とくに口蓋部 の薄肉部にC F クロスを埋入することは下影などの強化 義歯に比べ至難の業である。また上顎義歯床の床の強化 は床そのものが殸 (Shell) の構造をしているため, CF ク ロスによる補強効果はすぐれており, 口蓋部の床の板厚 も C F でクロス $0.5 \sim 0.6 \mathrm{~mm}$ とすることが可能である。

図 1 はCFクロスを強化材とした瀻維強化義歯床の成 形手順を示したもので, 成形法は義朄床を咬合面を形成 する顎底と口蓋部とに分けて，それぞれを別々に成形

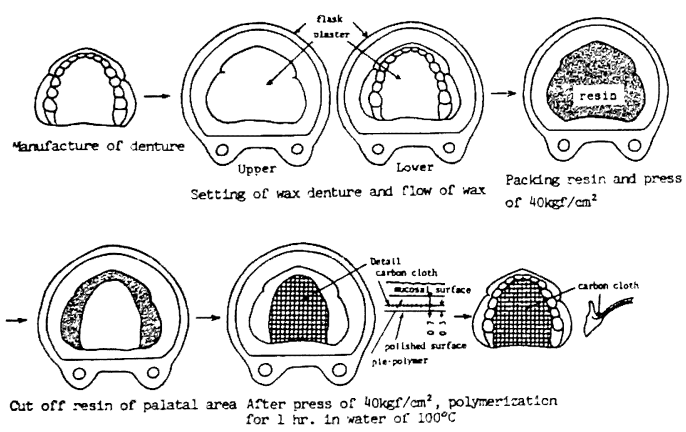

Fig. 1. The order making the denture base reinforced with carbon cloth
し，できる限り要求寸法に命った上顎義歯床を成形しよ 5 と考えたものである。

図 1 は上顎義歯床のワックスパターン以後の成形に関 し示したもので, 石こら型を作るまでは従来の成形法に 準じて行われる。そして,石こら型にレジンを充埧後は口 蓋部のレジンがまだ餅状のらちにスパチラなどを用いて ロ蓋部のレジンを削除する。一方, 口蓋部の強化義歯床 は歯科用アクリルモノマーを一定量入れた容器（シャー レ）にアクリルポリマーの-定出を表面が平らになるよ ら散布する。

つぎにあらかじめモノマーを十分含浸させたC F クロ ス（平織クロス）を置き，さらにポリマーを散布し，板 厚が0.5〜0. $6 \mathrm{~mm}$ となるよら製作する。そして,このよ らにレジンを含浸させかつ所定の形状にトリミングした $\mathrm{CF}$ クロスを口蓋部に設置し，石こうの上型を林口蓋部 上部に置き, 通常の成形法により加圧, 加熱により成形 は行われる。このとき上顎義米床の成形に際し, 床口 蓋部の歯科用アクリルレジンは餅状であり，また強化材 のCF クロスの位置, 方向等を十分確認のう克加圧し, 温熱重合することが大切である。

このように繊維強化上顎義米床はその成形法が従来の レジン床に比べ複雑で，かつ成形技術に依存することが 問題であるが，ここに示される方法に従えば，比較的バ ラッキも少なく, 安定した性能の上顎義歯床の成形が行 われる。

\section{文献}

1）宮入裕夫, 永井正洋, 高山義明, 他：日本複合材 料学会誌, 6(4) : 24, 1980 . 